\title{
Slag of thermal power plants as an attractive raw material
}

\section{for porous fillers production}

\author{
Diana Kindzera $^{1}$, Ihor Mitin ${ }^{2}$, Volodymyr Atamanyuk $^{3}$, Roram Hosovskyi ${ }^{4}$ \\ 1. Department of Chemical Engineering, Lviv Polytechnic National University, UKRAINE, Lviv, \\ 12 S. Bandery Str., E-mail: kindzera74@ukr.net
}

2. Department of Chemical Engineering, Lviv Polytechnic National University, UKRAINE, Lviv, 12 S. Bandery Str., E-mail: ihor.mitin.mxt.2020@lpnu.ua

3. Department of Chemical Engineering, Lviv Polytechnic National University, UKRAINE, Lviv, 12 S. Bandery Str., E-mail: atamanyuk@ukr.net

4. Department of Chemical Engineering, Lviv Polytechnic National University, UKRAINE, Lviv, 12 S. Bandery Str., E-mail: roma5477@meta.ua

\begin{abstract}
The possibility of using TPP slag as the raw material for the production of porous filler has been proved. This approach increases the savings of natural resources, reduces the cost of finished product and reduces the level of environmental pollution. Insignificant values of the pressure drop confirm the application feasibility of the filtration drying as an energy-saving method of the drying of slag and clay for the preparation of the charge for porous filler production. Obtained results on kinetics are useful for the organization and intensification of the filtration drying process of slag and clay as the preliminary stage at the porous fillers production line. The qualitative new porous filler with the bulk density of $230 \mathrm{~kg} / \mathrm{m}^{3}$, the specific heat of 0,82 $\mathrm{kJ} / \mathrm{kg} \cdot \mathrm{K}$, the thermal conductivity of $0,067 \mathrm{~W} / \mathrm{m}^{2} \cdot \mathrm{K}$ and with a compressive strength of $27,7 \mathrm{MPa}$ has been obtained which can be used for the production of lightweight concretes.
\end{abstract}

Keywords - thermal power plant (TPP), ash and slag wastes, utilization, porous filler, filtration drying, lightweight concrete.

\section{Introduction}

In recent years, the growing demand for electricity and heat has increased the number of worldwide thermal power plants (TPP). The operation of power plants leads to air pollution and the accumulation of significant amount of solid wastes such as slag and ash which are formed as a result of the solid fuel combustion, especially coal, and are stored in ash slag dumps. Most of the ash and slag dumps of Ukrainian thermal power plants are practically already filled, and there is no possibility to expand them due to lack of territory. Therefore, environmental management of ash slag is essential for individual thermal energy companies and Ukraine as a whole and finding the methods of waste utilization is an essential task.

One of the rational method of slag and fly ash utilization is to involve them in the production process, which corresponds to current trends in technology in industrialized countries. In order to develop cost-effective organizational and technical solutions for the management with the solid wastes of TPP, the experience of developed countries was taken into account and separate extraction of ash and slag was introduced at some TPPs of Ukraine. This technical solution allows to use dry ash as an additive for concrete, mortar, cement, as well as to use it for production of silicate products, glass ceramics and road construction [1,2].

One of the most efficient methods to reduce the slag volume is to transform it into potential resources. However, its humidity is very high caused by hydraulic method of removal and transportation to the dumps. Therefore, only a small amount of slag is used for industrial purposes.

Slag, which is formed in large quantities in coal-fired thermal power plants, is considered an attractive material for cost-effective porous fillers production creating new market opportunities. Reserves of well-bloating clay rocks as the raw materials for artificial porous fillers production are 
decreasing with every year. Therefore, the use of slags of TPP in the production of artificial porous fillers becomes actual [3].

Slag and clay, as the raw materials for industrial purposes, should be dried in view of it high moisture content. Since the cost of drying is a significant, finding alternative drying methods with designing new constructions of dryers is an urgent task. Therefore, to implement the drying process of slag and clay, we propose the filtration drying method which gives an opportunity to intensify mass and heat transfer processes and to reduce the drying agent amount, drying time and energy loss through outlet drying agent [4].

\section{Results and Discussions}

Comparing the chemical composition of clay and slag, we can observe that they are close to the main chemical components. Thus, to preserve the formulary capacity of the filler samples, part of the raw clay material can be replaced with slag. Furthermore, there is a greater amount of $\mathrm{Fe}_{2} \mathrm{O}_{3}$ in the slag $(20,6 \%)$ than in the clay $(6,5 \%)$, as well as sufficient amount of $\mathrm{Na}_{2} \mathrm{O}+\mathrm{K}_{2} \mathrm{O}(1,5+0,7 \%)$ in the slag that plays a big role in bloating under the influence of high temperatures. Thus, the possibility of using TPP slag as the raw material for the production of porous filler is proved.

Investigation of the hydrodynamics and kinetics of the filtration drying process of slag and clay was performed by using experimental plant. Insignificant values of the pressure drop confirm the application feasibility of the filtration drying as an energy-saving method of the drying of slag and clay. The influence of the drying agent temperature on the kinetic during filtration drying of slag and clay was investigated. Results in the form of graphs are represented in Fig. 1.
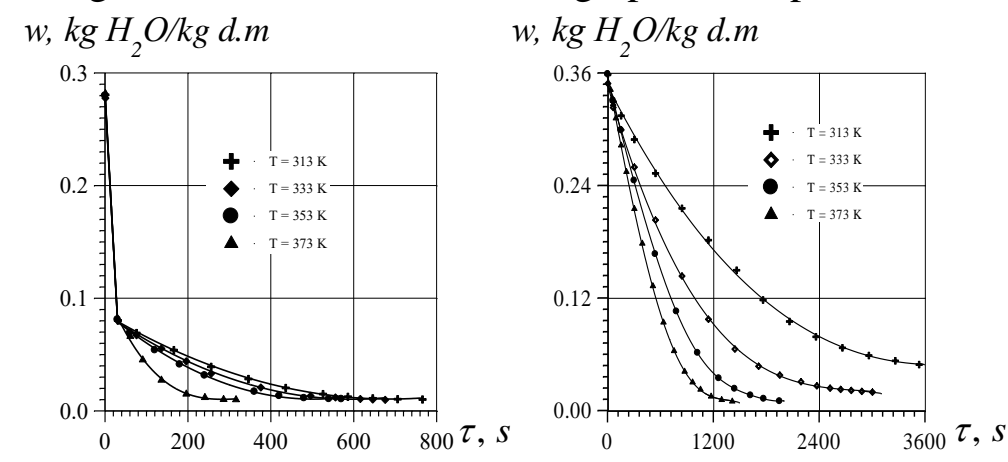

Fig. 1. The influence of the drying agent temperature on the kinetics during filtration drying of slag and clay: $\left(v_{0}=1,33 \mathrm{~m} / \mathrm{s}, H=0,12 \mathrm{~m}\right)$.

Obtained results (Fig. 1) are useful for the organization and intensification of the filtration drying process of slag and clay as the preliminary stage at the porous fillers production line.

Raw granules (samples of porous filler) were prepared in the form of cubes with size $15 \times 15 \times 15 \mathrm{~mm}$ by using a dispersed charge which includes clay 55\%, slag TPP $35 \%$, burning additives (sawdust and coal) 5\%, binding and gas-forming additives 5\%. The physical-mechanical properties of the filler prepared on base of TPP slag are shown in Table 1.

Table 1

Physical-mechanical parameters of the filler prepared on base of TPP slag

\begin{tabular}{|c|c|}
\hline Bulk density & $230 \mathrm{~kg} / \mathrm{m}^{3}$ \\
\hline Specific heat & $0,82 \mathrm{~kJ} /(\mathrm{kg} \cdot \mathrm{K})$ \\
\hline Thermal conductivity & $0,067 \mathrm{~W} /\left(\mathrm{m}^{2} \cdot \mathrm{K}\right)$ \\
\hline Compressive strength & $27,7 \mathrm{MPa}$ \\
\hline
\end{tabular}


The physical-mechanical properties of the porous filler obtained from TPS slag correspond to the requirements of DSTU B B.2.6-189: 2013 "Methods of selection of thermal insulation material for building insulation" and obtained filler can be recommended for the production of lightweight concretes.

\section{Conclusion}

The possibility of using TPP slag as the raw material for the production of porous filler has been proved. The main benefits of using such wastes in the production process are environmental protection, conservation of raw resources for the production of finished products.

Insignificant values of the pressure drop confirm the application feasibility of the filtration drying as an energy-saving method of the drying of slag and clay for the preparation of the charge for porous filler production and results of the kinetics investigation are useful for the organization and intensification of the filtration drying process of slag and clay as the preliminary stage at the porous fillers production line.

The qualitative new lightweight filler with the bulk density of $230 \mathrm{~kg} / \mathrm{m}^{3}$, the specific heat of $0,82 \mathrm{~kJ} / \mathrm{kg} \cdot \mathrm{K}$, the thermal conductivity of $0,067 \mathrm{~W} / \mathrm{m}^{2} \cdot \mathrm{K}$ and with a compressive strength of 27,7 $\mathrm{MPa}$ has been obtained which can be used for the production of lightweight concretes.

\section{References}

[1]. Cheng T.W., Chen Y.S. (2004). Characterisation of glass ceramics made from incinerator fly ash. v. 30, 343-349. https://doi.org/10.1016/S0272-8842(03)00106-8 (Ceramics International).

[2]. Ahmaruzzaman M., (2010). A review on the utilization of fly ash, v. 36, 327-363. https://doi.org/10.1016/j.pecs.2009.11.003 (Progress in Energy and Combustion Science).

[3]. Mammadov H., Suleymanova I. (2010). An artificial porous gravel based on slags of thermal power stations. v. 9, Issue, 11(C), 29645-29649. http://dx.doi.org/10.24327/ijrsr.2018.0911.2899 (International Journal of Recent Scientific Research).

[4]. Hosovskyi, R., Kindzera, D., Atamanyuk, V. (2016). Diffusive mass transfer during drying of grinded sunflower stalks. v. 10(4), 459-464. https://doi.org/10.23939/cte2019.01.105 (Chemistry \& Chemical Technology). 